\title{
Titres of Specific Antibodies against Toxoplasma gondii in Goats and their Kids
}

\author{
L'ubica Mišurová ${ }^{1}$, Vlasta Svobodová ${ }^{2}$, Leoš Pavlata $^{1}$, Rudolf Dvořák ${ }^{1}$ \\ ${ }^{1}$ Clinic of Diseases of Ruminants, ${ }^{2}$ Department of Parasitology, Faculty of Veterinary Medicine, \\ University of Veterinary and Pharmaceutical Sciences Brno, Czech Republic
}

Received February 15, 2008

Accepted December 15, 2008

\begin{abstract}
The aim of our study was to perform repeated determination of specific antibody levels in mothers and their kids in order to assess indirectly the possibility of vertical transmission of toxoplasmosis in goats. Twenty-eight goats with their kids were included in the study. The following variables were assessed: number of born kids in relation to antibody titres of goats; levels of specific antibodies in the blood of goats and kids; and concentrations of immunoglobulins (Ig), total protein (TP) and total globulins (G) in order to define the end of colostral immunity and the start of active production of antibodies in kids under 69 days of age.

Specific antibodies against Toxoplasma gondii in goats were detected by IFAT in titres ranging from 0 to 1280 . Out of a total of 28 animals, 5 goats were negative $(17.9 \%)$ and 23 goats were seropositive $(82.1 \%)$. The goats delivered 42 kids. A total ratio of number of kids to number of mothers was 1.5. Partial evaluation of results in goats without positive titre against T. gondii before parturition and goats with positive titre showed that negative goats tended to have more kids $(p<0.1)$ (ratio 1.80) compared to positive goats (ratio 1.35). A significant decrease in levels of TP, Ig and G was observed between days 27 and 41. Samples taken on days 55 and 69 proved gradual increase of active production of antibody response, which was supported also by a significant increase $(p<0.01)$ of monitored non-specific immunity indicators. During this period, we observed increased titres of specific antibodies against toxoplasmosis in 20 kids (5 kids 41 days old, 5 kids 55 days old, and 10 kids 69 days old) and thus we could assume the possibility of vertical transmission of toxoplasmosis.
\end{abstract}

Immunoglobulins, colostral immunity, small ruminants, zoonosis

The protozoan parasite Toxoplasma gondii has been thoroughly studied for a long time. As this zoonotic pathogen affects both animals and humans, attention is paid also to animals whose meat is used for human consumption in order to ensure food safety (Hill and Dubey 2002; Lhafi et al. 2004). Human toxoplasmosis has been discussed mainly as the cause of abortions and congenital foetal defects. Mc Allister (2005) drew attention to human dormant toxoplasmosis that might affect cerebral activity. Pasture animals are most often infected by Toxoplasma gondii oocysts produced by their definitive hosts, i.e. cats. It has been proven that there is a direct correlation between the presence of cats on farms and the incidence of specific antibodies against $T$. gondii in livestock (Skjerve et al. 1998). Interestingly, small ruminants such as sheep and goats show similar transplacental transmission of toxoplasmosis as humans. It is presumed that the transmission occurs during acute infection in pregnancy. Abortions are observed during early pregnancy period. Pereira-Bueno et al. (2004) proved that $23.1 \%$ of abortions in sheep studied in Spain are caused by toxoplasmosis. If the infection occurs later, kids are born healthy (Blewet et al. 1982). Recent studies show that the infection in small ruminants can be also transmitted vertically from mothers with chronic latent toxoplasmosis (Duncanson et al. 2001; Buxton et al. 2006), which results in higher prevalence in herds. This finding is very important, as the incidence of sheep and goat toxoplasmosis is relatively high in most countries. In the Czech Republic, specific antibodies were detected in 20\% of goats in 1995 (Literák et al. 1995) and 66\% goats in 1999 (Šlosárková et al. 1999).

Phone: +420541562411

Fax: +420 549248841

E-mail: lmisurova@vfu.cz

http://www.vfu.cz/acta-vet/actavet.htm 
The present study of toxoplasmosis in goats compares and evaluates repeatedly determination of specific antibody levels in goats and their kids.

\section{Materials and Methods}

Twenty-eight white shorthaired goats born in 2005 were bought from eleven different Czech farms. Goats were housed at the Clinic of Diseases of Ruminants and fed hay ad libitum and $350 \mathrm{~g}$ of granules per goat twice a day. Goats had constant access to drinking water. As soon as they reached $35 \mathrm{~kg}$ of body weight, they were mated. After parturition, the kids stayed with their mothers until they reached 69 days of age. The amount of feed was increased after parturition and divided to three portions per day. Beside pelletted feed ( $600 \mathrm{~g}$ per goat), the goats were given barley meal ( $450 \mathrm{~g}$ per goat and day). All parturitions were controlled. Immediately after parturition, each newborn kid was subjected to a standard medical examination and then suckled by its mother ad libitum.

Samples of kid blood were taken on days $0,2,6,13,27,41,55$ and 69 after parturition in order to determine levels of immunoglobulins (Ig), total protein (TP) and total globulins (G). Specific antibodies against toxoplasmosis were determined in mother serum taken before parturition and in kid serum taken on days 27, 41, 55 and 69 after parturition. Blood samples were taken from vena jugularis. Specific antibodies against naturally acquired toxoplasmosis were detected by indirect fluorescence (IFAT) using TOXO-RH strain as antigen (Zeus Scientific, Inc., USA) and goat conjugate Anti-Goat IgG (whole molecule) FITC Conjugate (Sigma) at a dilution of 1:40 to the final positive titre. Total protein was determined by photometry using Cobas Mira (Roche Switzerland)

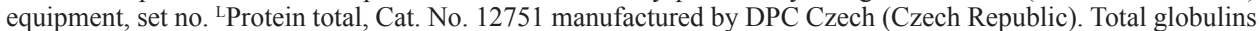
were calculated as a difference of total protein and albumin (determined by photometry with bromcresol green, set

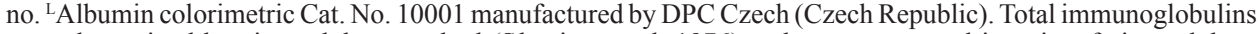
were determined by zinc sulphate method (Slanina et al. 1976) and were expressed in units of zinc sulphate turbidity (UZST).

Basic statistical characteristics of the sample of determined values (mean, standard deviation) and evaluation of changes in TP, G and Ig values (using paired Student's $t$-test) were processed in Microsoft Excel XP spreadsheet. Numbers of newborn kids and numbers of mothers across individual groups were compared using chi square test.

\section{Results}

Twenty-eight goats delivered 42 kids; one twin kid died of trauma. Although there were no abortions, one goat suffered from hydrometra. Parturition of twins prevailed (15), triplets were born once, a single kid was born 9 times and 3 goats did not become pregnant at all. The total ratio of the number of kids to the number of mothers was 1.5. Partial evaluation of the results in goats without positive titre against $T$. gondii before parturition and goats with positive titre showed that the negative goats tended to have more kids $(p<0.1)$ (ratio 1.80) compared to the positive goats (ratio 1.35).

Table 1. The titres of specific antibodies against $T$. gondii of goats and the number of their kids

\begin{tabular}{|c|c|c|c|c|c|c|}
\hline \multirow{2}{*}{ Titre } & \multirow{2}{*}{$\begin{array}{c}\text { Number of } \\
\text { mothers }\end{array}$} & \multirow{2}{*}{$\begin{array}{c}\text { Non- } \\
\text { pregnant } \\
\text { goats }\end{array}$} & \multicolumn{4}{|c|}{ Number of born kids } \\
\cline { 5 - 7 } & & & One kid & Twins & Triplet & Total \\
\hline Negative & 5 & 0 & 1 & 4 & 0 & 9 \\
\hline 40 & 3 & 0 & 1 & 2 & 0 & 5 \\
\hline 80 & 7 & 0 & 2 & 5 & 0 & 12 \\
\hline 160 & 4 & 1 & 2 & 1 & 0 & 4 \\
\hline 320 & 2 & 0 & 1 & 1 & 0 & 3 \\
\hline 1280 & 7 & 2 & 2 & 2 & 1 & 9 \\
\hline Total & 28 & 3 & 9 & 15 & 1 & 42 \\
\hline
\end{tabular}

Specific antibodies against Toxoplasma gondii in goats were detected in titres ranging from 0 to 1280 . Out of a total of 28 animals, 5 goats were negative $(17.9 \%)$ and 23 goats were positive $(82.1 \%)$. Numbers of mothers sorted by titres and numbers of their kids are demonstrated in Table 1. Four blood samples of kids were examined. Specific antibodies were determined in titres ranging from 0 to 1280 . No monitored animal showed any clinical signs of the disease. Titres of kids of mothers sorted by determined titres are 
Table 2. The titres of specific antibodies against $T$. gondii in mothers and their kids (* marks sampling which observed increasing of titre of antibodies in kid)

\begin{tabular}{|c|c|c|c|c|}
\hline \multirow[b]{2}{*}{ Mother titre } & \multicolumn{4}{|c|}{ Kid titre } \\
\hline & $\begin{array}{c}\text { Sampling } 1 \\
27 \text { days of age }\end{array}$ & $\begin{array}{c}\text { Sampling } 2 \\
41 \text { days of age }\end{array}$ & $\begin{array}{c}\text { Sampling } 3 \\
55 \text { days of age }\end{array}$ & $\begin{array}{l}\text { Sampling } 4 \\
69 \text { days of age }\end{array}$ \\
\hline \multirow[t]{2}{*}{0} & 0 & 0 & 0 & $80^{*}$ \\
\hline & 0 & 0 & 0 & $40 *$ \\
\hline \multirow[t]{2}{*}{0} & 40 & 0 & 0 & $40 *$ \\
\hline & 0 & 0 & 0 & $40 *$ \\
\hline \multirow[t]{2}{*}{0} & 40 & 0 & 0 & 0 \\
\hline & 40 & 0 & 0 & $40 *$ \\
\hline \multirow[t]{2}{*}{0} & 80 & 40 & $80 *$ & 80 \\
\hline & 40 & 40 & 0 & 0 \\
\hline 0 & 0 & $40 *$ & 40 & 40 \\
\hline \multirow[t]{2}{*}{40} & 0 & $320 *$ & 320 & 160 \\
\hline & 0 & $80 *$ & 80 & 80 \\
\hline \multirow[t]{2}{*}{40} & 80 & 80 & 80 & 80 \\
\hline & 160 & 160 & 80 & \\
\hline 40 & 40 & 40 & 0 & $40 *$ \\
\hline 80 & 0 & 0 & 0 & 0 \\
\hline \multirow[t]{2}{*}{80} & 40 & 40 & 40 & 40 \\
\hline & 0 & $40 *$ & 40 & 40 \\
\hline \multirow[t]{2}{*}{80} & 40 & 40 & 40 & 40 \\
\hline & 40 & 40 & 0 & 0 \\
\hline \multirow[t]{2}{*}{80} & 640 & 80 & 80 & $160 *$ \\
\hline & 640 & 80 & 80 & 40 \\
\hline \multirow[t]{2}{*}{80} & 40 & 40 & 40 & 40 \\
\hline & 0 & $40 *$ & 40 & 40 \\
\hline \multirow[t]{2}{*}{80} & 40 & 40 & 40 & 40 \\
\hline & 40 & 0 & $40 *$ & 40 \\
\hline 80 & 40 & 0 & 0 & 0 \\
\hline 160 & 0 & 0 & $40 *$ & 40 \\
\hline \multirow[t]{2}{*}{160} & 160 & 40 & 40 & 40 \\
\hline & 40 & 40 & 40 & 40 \\
\hline 160 & 160 & 40 & 40 & $80 *$ \\
\hline \multirow[t]{2}{*}{320} & 320 & 80 & 80 & 80 \\
\hline & 80 & 80 & 80 & 80 \\
\hline 320 & 640 & 80 & $160 *$ & 160 \\
\hline \multirow[t]{2}{*}{1280} & 1280 & 640 & 640 & 640 \\
\hline & 1280 & 80 & $320 *$ & 320 \\
\hline \multirow[t]{3}{*}{1280} & 1280 & 1280 & 640 & 640 \\
\hline & 1280 & 640 & 640 & 320 \\
\hline & 1280 & 640 & 640 & 320 \\
\hline \multirow[t]{2}{*}{1280} & 160 & 0 & 0 & 0 \\
\hline & 640 & 80 & 0 & $80 *$ \\
\hline 1280 & 1280 & 640 & 320 & 160 \\
\hline 1280 & 640 & 160 & 80 & $160 *$ \\
\hline
\end{tabular}

demonstrated in Table 2. Figs 1-6 demonstrate mean titres of kids of mothers with different titres. The figures and Table 2 prove that titres of specific antibodies increased in many kids (20) during the study. 

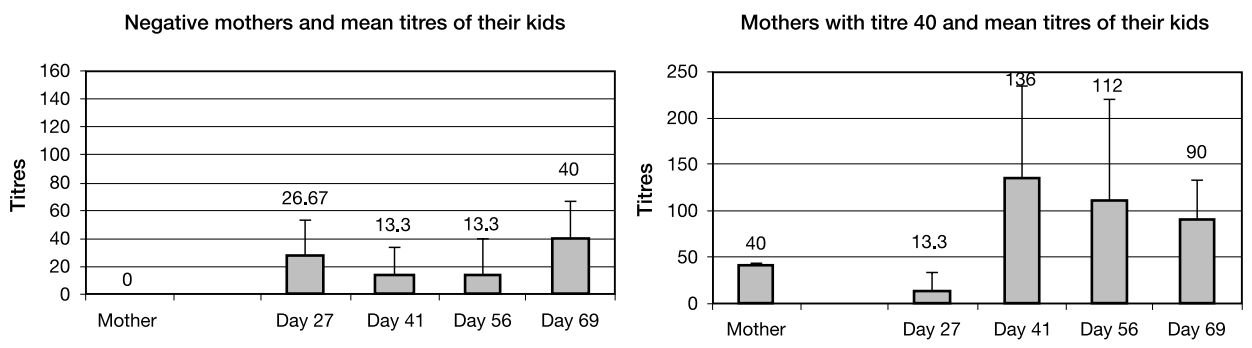

Mothers with titre 80 and mean titres of their kids
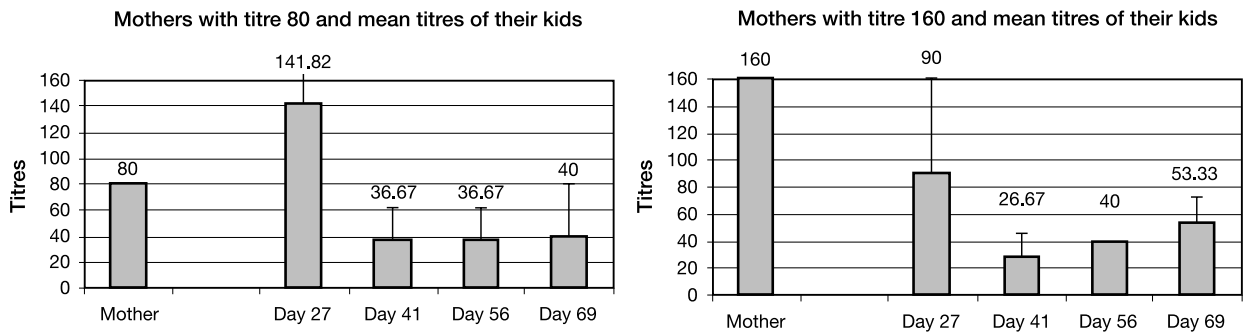

Mothers with titre 320 and mean titres of their kids
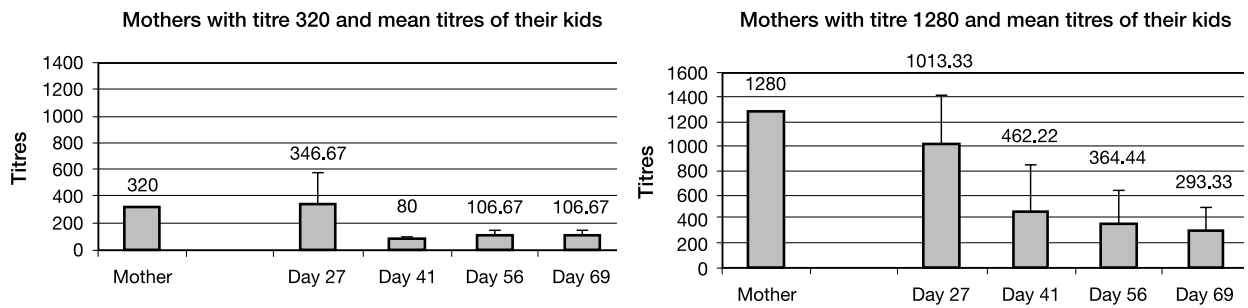

Figs 1-6. The titres of mothers and titres (mean \pm S.D.) of their kids in individual samplings

The assessment of changes in TP, G and Ig concentrations showed an initial significant increase $(p<0.01)$ of all monitored indicators (caused by colostrum intake) and subsequent gradual decrease of the values until day 27 or 41 after parturition (Figs 7-9). A significant decrease $(p<0.01)$ of total immunoglobulins, total protein and total globulins was observed between days 27 and 41 . The lowest Ig (12.6 UZST) and G $\left(22.1 \mathrm{~g} \cdot \mathrm{l}^{-1}\right)$ mean values were observed on day 27 . TP value measured on day 27 was $55.7 \mathrm{~g} \cdot \mathrm{l}^{-1}$; values measured during later samplings were even slightly lower. Concentrations of the monitored variables showed a gradual increase from day 41 (or from day 55 in TP). A significant increase $(p<0.01$ ) was noted on day 55 or 69 after parturition.

The assessment of the relationship between antibody titres in mothers before parturition and antibody titres of their kids proved significant correlation $(\mathrm{r}=0.85 ; p<0.01)$ measured in samples taken on day 27 (Fig. 10). Samples taken later showed substantially weaker correlation between antibody titres of mothers and kids $(\mathrm{r}=0.66)$.

\section{Discussion}

It seems that vertical transmission of toxoplasmosis plays a much more important role compared to horizontal transmission (via oocysts shed in cat faeces) than was believed (Hide et al. 2006). Although vertical transmission in small ruminants was studied mainly in sheep (Buxton et al. 2006; Mas on et al. 2006), we presume that similar mechanism can be found in goats, too. The prevalence of toxoplasmosis in goats is relatively high. Antonis et al. 
TP

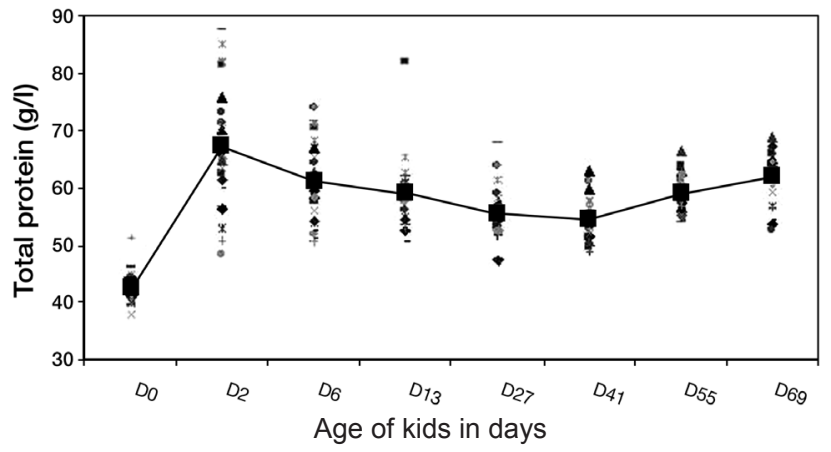

G

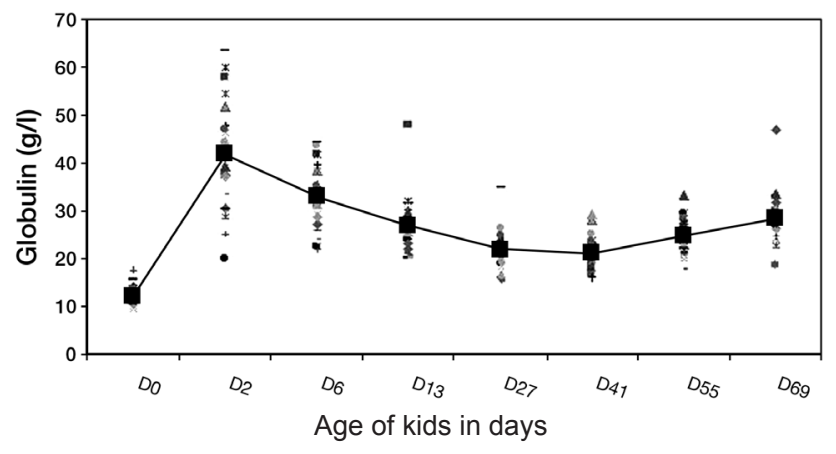

$\lg$

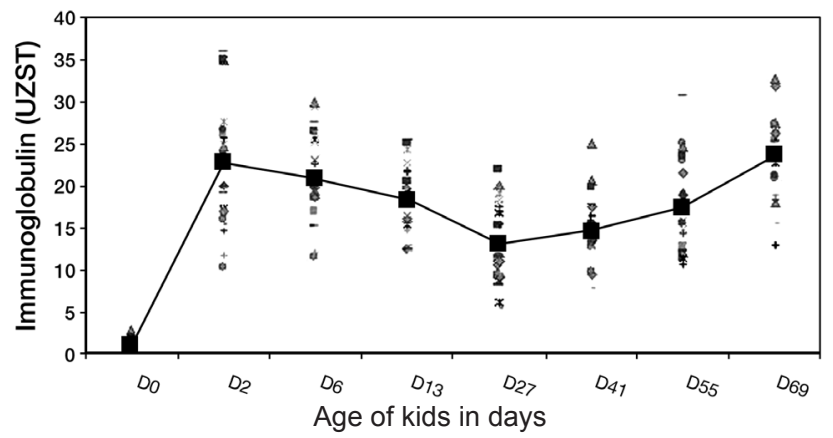

Figs 7-9. Dynamics of changes in total protein (TP), globulin (G) and immunoglobulin concentrations (Ig) in kids blood serum measured from parturition to 69 days of age (values of individual animals are marked; mean group value in individual samplings is highlighted)

(1998) found specific antibodies in 47\% goats in the Netherlands; Stimbirys et al. (2006) determined antibodies in $52.63 \%$ dairy goats in Poland. In the Czech Republic, specific antibodies were detected in 20\% and 66\% goats in 1995 and 1999, respectively (Literák et al. 1995; Šlosárková et al. 1999). The results of our experiment with 28 randomly bought goats indicates a high prevalence, too ( $82.1 \%$ of animals were seropositive). 


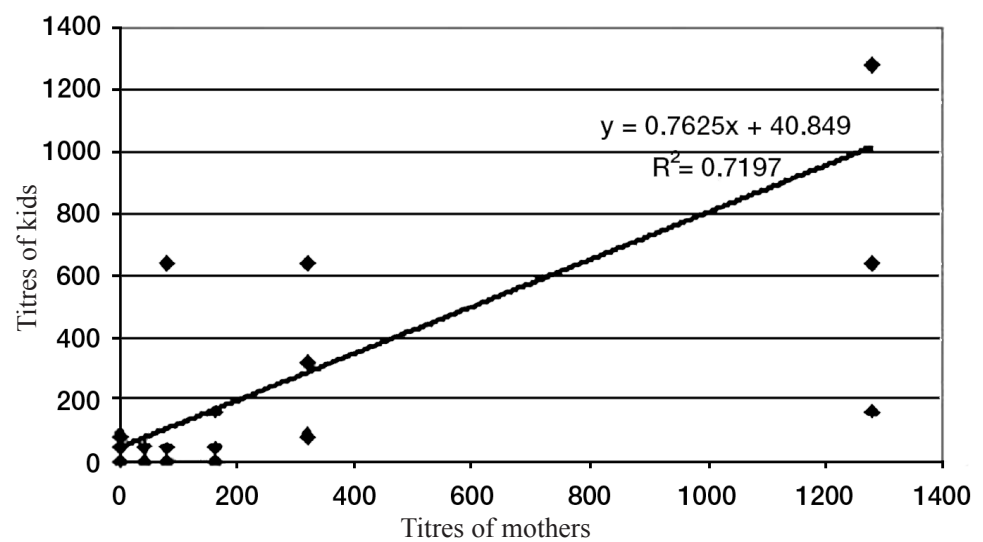

Fig. 10. Correlation between the titre of specific antibodies against $T$. gondii in mothers before parturition and in kids 27 days after parturition

Our study of vertical transmission of toxoplasmosis in goats was based on indirect methods. We monitored numbers of born kids and observed seroconversion of specific antibodies. Although no animal showed any clinical signs of toxoplasmosis during the study, we noted possible connection with the pathogenic change of prenatal development of foetuses. Although we observed no abortion, one goat with titre 160 suffered from hydrometra that resulted in foetal death. We noted a significant tendency $(p<0.1)$ of goats without positive antibody titre to have more kids. Two mothers of seven goats with a high titre of 1280 did not become pregnant, so we should consider the possibility of early embryonic death. Latent toxoplasmosis is a very frequent condition. Ryniewicz et al. (2003) did not observe any clinical manifestations in serologically positive goats, though they detected antibodies in $46.6 \%$ of examined animals. Toxoplasmosis as the cause of abortion was confirmed only in $4 \%$ out of 211 aborting goats in the U.S., California (Moeller 2001) compared to $23.1 \%$ of goats studied in Spain (Pereira-Bueno et al. 2004).

In our study, specific antibodies found in mothers were compared to antibody levels determined in four blood samples taken from kids. We found that colostral immunity represented by acquired antibodies persists until days 27 to 41 (Fig. 7), when we noted a significant decrease in antibody levels $(p<0.01)$. Mikula et al. (2001) reported that the half-life of passively acquired immunoglobulins in small ruminants was 16-32 days for IgG1 and $\operatorname{IgG} 2,4$ days for IgM and 2.5 day for Ig A. The first and second sampling (days 27 and 41 after birth) was probably influenced by residual colostral immunity, which resulted in the detection of higher antibody levels. Samples taken on days 55 and 69 proved gradual increase of active production of antibody response, which was supported also by a significant increase $(p<0.01)$ of monitored non-specific immunity indicators. During this period, we observed increased titres of specific antibodies against toxoplasmosis in 20 kids (Table 2). Mean titres of specific antibodies against toxoplasmosis in kids corresponded with the titres of their mothers, especially during the period of colostral immunity. Significant correlation $(\mathrm{r}=0.85 ; p<0.01)$ was confirmed by samples taken on day 27 . Nevertheless, we noted a certain discrepancy in negative mothers and their kids (Fig. 1) - low titres of specific antibodies were detected in the kids of negative mothers. This was probably caused by the fact that we did not monitor titres under the dilution of 1:40 (i.e. goats with lower levels were marked as negative). Even if we have to consider also non-specific reaction in the low titre of 40, we maintain the stated opinion. Our group of kids from negative mothers had 9 kids. 
Of these, 4 had titre 40, 1 kid titre 80 and 4 were negative. Active production of antibodies observed after days 55 and 69 indicated a less close relation between antibody values in mothers and kids. Correlation calculated from samples taken later was substantially weaker $(r=0.66)$ and was affected by the activity of the immune system of individual kids. Vertical transmission can be influenced also by virulence of the specific strain of T. gondii (Buxton et al. 2006). Unfortunately, accurate data concerning small ruminants are not available. In the Czech Republic, twenty $T$. gondii strains were isolated and tested by RFLP method between 1994 and 1995 (Literák et al. 1998). Of these 20 strains, 19 belonged to an avirulent lineage and only 1 was classified as belonging to virulent lineage. Non-pathogenic cyst-producing strains are believed to cause latent toxoplasmosis whose potential hazard should be considered mainly in humans. Latent toxoplasmosis is reported to be a possible cause of cerebral disorders (Flégr et al. 1996; 2003). Toxoplasmosis of goats can infect humans not only via meat but also tachyzoites present in non-pasteurized milk (Tender et al. 2000).

The results of the present study indicate vertical transmission only indirectly. By defining the end of colostral immunity, we confirmed the antibody response of kids to T. gondii. Persistence or gradual increase of antibody levels observed from day 55 might be induced by active toxoplasmosis acquired vertically. Based on previous knowledge of vertical transmission of toxoplasmosis in sheep, our study showed that vertical transmission of toxoplasmosis in goats is a relatively frequent condition that causes a high prevalence and spreading of toxoplasmosis in goat herds.

\section{Titry specifických protilátek proti Toxoplasma gondii u koz a jejich kůzlat}

Cílem práce bylo sledování opakovaným stanovením titrů specifických protilátek u koz a jejich kůzlat nepř́mo posoudit možnost vertikálního přenosu toxoplazmózy koz. Do sledování bylo zařazeno $28 \mathrm{koz}$ a jejich kůzlata. V rámci studie bylo vyhodnoceno: počet narozených kůzlat ve vztahu k titru protilátek u jejich matek; titry specifických protilátek v krvi koz a kůzlat; koncentrace imunoglobulinů (Ig), celkové bílkoviny (TP) a globulinů (G) pro vyhodnocení poklesu kolostrální imunity a nástupu aktivní produkce protilátek u kůzlat do 69 dnů jejich věku.

Titry specifických protilátek proti Toxoplasma gondii u koz před porodem se pohybovaly $\mathrm{v}$ rozmezí od 0 do 1280 . Z 28 vyšetřených koz bylo na protilátky proti $T$. gondii 5 zvířat negativních $(17,9 \%)$ a u 23 byla prokázána séropozitivita $(82,1 \%)$. Od vyšetřovaných 28 koz se narodilo 42 kůzlat. Celkový poměr počtu kůzlat ve vztahu k počtu matek byl 1,5. Kozy, které byly před porodem séronegativní, měly vyšší počet kůzlat než kozy, které byly séropozitivní $(p<0,1)$. K průkaznému poklesu TP, Ig a G v krvi kůzlat došlo mezi 27. až 41. dnem jejich věku s následným postupným zvyšováním aktivní produkce protilátek $(p<0,01)$ mezi 55. až 69. dnem jejich věku. Během tohoto období jsme také zaznamenali zvýšení titrů specifických protilátek proti $T$. gondii u 20 z jednotlivých vyšetřovaných kůzlat (5 kůzlat ve věku 41 dní, 5 kůzlat ve věku 55 dní a 10 kůzlat ve věku 69 dní), což upozorňuje na možný vertikální přenos toxoplazmózy.

\section{Acknowledgements}

The work was supported by the Research Project of the Ministry of Education, Youth, and Sports No. MSM6215712403.

\section{References}

Antonis AFG, Van Knapen F, Dercksen DP, Jager PM 1998: Toxoplasmosis in goats in the Netherlands. Tijdschr Diergeneesk 123: 561-565

Buxton D, Rodger SM, Maley SW, Wright SE 2006: Toxoplasmosis: The possibility of vertical transmission. Small Rum Res 62: 43-46 
Blewet DA, Miller JK, Buxton D 1982: Response of immune and susceptible ewes to infection with Toxoplasma gondii. Vet Rec 111: 175-178

Duncanson P, Terry RS, Smith JE, Hide G 2001: High levels of congenital transmission of Toxoplasma gondii in a commercial sheep flock. Int J Parasitol 31: 1699-1703

Flégr J, Zitkova S, Kodym P, Frynta D 1996: Induction of changes in human behavior by the parasitic protozoan Toxoplasma gondii. Parasitol 113: 49-54

Flégr J, Preiss M, Klose J, Havlicek J, Vitakova M, Kodym P 2003: Decreased level of psychobiological factor novelty seeking and lower intelligence in men latently infected with the protozoan parasite Toxoplasma gondii Dopamine, a missing link between schizophrenia and toxoplasmosis? Biol Psychol 63: 253-268

Hide G, Williams RH, Morley EK, Hughes JM, Thomasson D, Murphy RG, Smith JE 2006: Evidence for high levels of vertical transmission in Toxoplasma gondii. CD-ROM, Proc. ICOPA XI, Glasgow

Hill D, Dubey JP 2002: Toxoplasma gondii: transmission diagnosis and prevention. Clin Microbiol Infect 8: 634-640

Lhafi SK, Mitzscherling AT, Kuhne M 2004: Parasitic hazards in meat: a challenge for veterinarians in meat hygiene. Deut Tierarztl Woch 111: 277-281

Literák I, Skřivánek M, Skalka B, Celer V Jr. 1995: Antibodies to some infections on large goat farms in the Czech Republic. Vet. Med. - Czech 40: 133-136

Literák I, Rychlík I, Svobodová V, Pospíšil Z 1998: Restriction fragment length polymorphism and virulence of Czech Toxoplasma gondii strains. Int J Parasitol 28: 1367-1374

Mason S, Nieuwhof G, Smith J 2006: Congenital transmission of Toxoplasma gondii in UK sheep, CD-ROM, Proc. ICOPA XI, Glasgow.

McAllister MM 2005: A decade of discoveries in veterinary protozoology changes our concept of "subclinical" toxoplasmosis. Vet Parasitol 132: 241-247

Mikula L, Ferenčík M, Tkáčiková L 2001: Immunoglobulins. In Kováč G et al. 2001: Disease of Cattle (In Slovak), M\&M vydavatel'stvo, Prešov, pp. 66-68

Moeller RB 2001: Cause of caprine abortion: diagnostic assessment of 211 cases (1991-1998). J Vet Diagn Invest 13: $265-270$

Pereira-Bueno J, Quintanilla-Gozalo A, Perez-Perez V, Alvares-Garcia C, Collantes-Fernandez E, Ortega-Mora LM 2004: Evaluation of ovine abortion associated with Toxoplasma gondii in Spain by different diagnostic techniques. Vet Parasitol 121: 33-43

Ryniewicz Z, Hulas C, Kaba J, Klockiewicz M, Bagnicka E 2003: Prevalence of Toxoplasma gondii in milk herds of Polish goats. Med Weter 59: 1043-1045

Skjerve E, Waldeland H, Nesbakken T, Kapperud G 1998: Risk factors for the presence of antibodies to Toxoplasma gondii in Norwegian slaughter lambs. Prev Vet Med 35: 219-227

Slanina L, Vajda V, Blažej J 1976: Turbidimetric analysis of immunoglobulins in calves and their clinical evaluation (In Slovak). Veterinářství 9: 392-394

Stimbirys A, Bagdonas J, Jokimas J, Nekrosiene N 2006: Dairy goats - indicators of some zoonotic pathogens in the environment. Med Weter 62: 644-648

Šlosárková S, Literák I, Skřivánek M, Svobodová V, Suchý P, Herzig I 1999: Toxoplasmosis and iodine deficiency in Angora goats. Vet Parasitol 81: 89-97

Tender AM, Heckeroth AR, Weiss LM 2000: Toxoplasma gondii: from animals to humans. Int J Parasitol 30: 1217-1258 